\title{
Application of principal component analysis to the indicators of water exchange of triticale shoots under $\mathrm{NaCl}$ stress
}

\author{
(C) Viktor V. Ivanishchev \\ Department of Biology and Technologies of Living Systems. Tula State Lev Tolstoy Pedagogical University. \\ Lenin Ave., 125. Tula, 300026. Russia.Phone:+7 (4872)65-78-08.E-mail: avdey_VV@mail.ru
}

Keywords: triticale, shoots, sodium chloride stress, water exhange, stress indicators, principal component analysis, cluster analysis.

\begin{abstract}
The results of the study of the water regime characteristics (without and taking into account the indicators of oxidative stress) of triticale shoots under conditions of short-term $\mathrm{NaCl}$ stress were analyzed with the principal component analysis (PCA). It is shown that the water content is the most stable indicator of triticale shoots under experimental conditions. The results of the analysis led to the conclusion that its value is not determined by the value of stomatal conductivity and/or transpiration. Determination of the correlation coefficients between the studied characteristics yielded negative values between the water content and other indicators of the water regime, as well as oxidative stress, except for the value of lipid peroxidation (LPO) (0.67). Despite the closest relationship between the water content and the osmotic potential according to the results of cluster analysis, the correlation between them was negative $(-0.76)$. This can be explained by different physiological and biochemical mechanisms that support each of these indicators. It is also shown that manifestations of oxidative stress are closely related to the osmotic potential and water content. In this case, the formation of a first-order cluster was observed between the content of water and hydrogen peroxide. This is not unexpected, but the correlation coefficient between them was only 0.018 . This value can be interpreted in such a way that water is needed for the formation of hydrogen peroxide, but their quantitative ratio (water : hydrogen peroxide) in the shoots of triticale is significantly different. The inclusion in the analysis of the results of the accumulation of salt ions showed a closer relationship between the increase in the content of salt ions and the change in transpiration, stomatal conductivity and the content of proline than with the water content in the shoots of triticale under experimental conditions.
\end{abstract}

\section{References}

[1] V.V. Ivanishchev On the possibility of an applying the method of cluster analysis to results of physiological-biochemical investigations of plants. Izvestiya Tul'skogo Gos. Univer. Yestesvenniye Nauki. 2018. Iss.1. P.69-77. (russian)

[2] V.V. Ivanishchev. On the application of statistical methods in the study of stress in plants and their selection. The bulletin of Kharkiv national agrarian university. Series Biology. 2018. Iss.3(45). P.111118. https://doi.org/10.35550/vbio2018.03.111.

[3] V.V. Ivanishchev. Revising the application of mathmethods in biological researches. Vestnik GOU DPO TO "IPK i PPRO TO". Tul'skoye obrazovatel'noye prostranstvo. 2018. No.3. P. 92-95. El. No. FS 7759888.

[4] E.A. Abramova, V.V. Ivanishchev. Characteristics of vetch seed germination in the presence of nickel ions in the medium. Izvestiya Tul'skogo Gos. Univer. Yestesvenniye Nauki. 2016. Iss.2-3. P.70-78. (russian)

[5] V.V. Ivanishchev, and N.N. Zhukov. Manifestations of oxidative stress in sprouts of triticale under condition of short-term exposure of sodium chloride Butlerov Communications. 2017. Vol.52. No.11. P.123-130. https://doi.org/10.37952/ROI-jbc-02/17-52-11-123

[6] V.V. Ivanishchev, and N.N. Zhukov. On the interrelation of water exchange and photosynthesis in triticale sprouts with short-term action of sodium chloride Butlerov Communications. 2018. Vol.53. No.3. P.35-42. https://doi.org/10.37952/ROI-jbc-02/18-53-3-35

[7] Viktor V. Ivanishchev. Investigation of the effect of short-term salt stress with the method of cluster analysis. Butlerov Communications. 2018. Vol.54. No.4. P.134-139. https://doi.org/10.37952/ROI-jbc02/18-54-4-134 
[8] V.V. Ivanishchev. The application of principal component analysis and cluster analysis to research of vetch seed germination in the presence of nickel chloride in the medium. Butlerov Communications. 2018. Vol.56. No.10. P.149-155. https://doi.org/10.37952/ROI-jbc-02/18-56-10-149

[9] V.V. Ivanishchev, T.N. Evgrashkina, O.I. Boykova, N.N. Zhukov. Effect of sulfate salinization on growth activity and water exchange of winter triticale cultivar "Tribune". Vestnik Voronezh State University, Series: Chemistry. Biology. Pharmacy. 2019. No.3. P.34-41. (russian)

[10] N.N. Zhukov, A.R. Garifzyanov, V.V. Ivanishchev. Dynamics of the antioxidant enzymes activity in $x$ Triticosecale organs at $\mathrm{NaCl}$ salinization. Izvestiya Tul'skogo Gos. Univer. Yestesvenniye Nauki. 2012. Iss.2. P.285-291. (russian)

[11] Metod glavnykch komponent. http://xn--c1acc6aafa1c.xn--p1ai/?page_id=2252.

[12] D.A. Shabanov, M.A. Kravchenko. Statisticheskii analiz dannikch v zoologii i ecologii. 2011. https://batrachos.com/biostatistica. (russian)

[13] N.N. Bureeva. Multidimensional statistical analysis with an application of "STATISTICA" software package. Nyzhnii Novgorod: NNGU. 2007. 112p. (russian)

[14] H.W. Heldt, B. Piechulla. Plant Biochemistry (4 ed.). Amsterdam et al.: Academic Press is an imprint of Elsevier. 2011. 647p. 